\title{
IAMJ
}

INTERNATIONAL

AYURVEDIC

MEDICAL JOURNAL

\section{CONCEPTUAL STUDY OF CORONA VIRUS DISEASE (COVID-19) IN RELATION WITH SANNIPATIK JWARA: AN AYURVEDIC PERSPECTIVE}

\author{
R. Govind Reddy ${ }^{1}$, Zaheer Z. Choudhari ${ }^{2}$ \\ ${ }^{1}$ Asst. Director, Regional Ayurveda Research Institute for Mother and Child Health, \\ Nagpur, Maharashtra- 440009, India \\ ${ }^{2}$ SRF (Ayu.), Regional Ayurveda Research Institute for Mother and Child Health, CCRAS, Ministry of \\ Ayush, Nagpur, Maharashtra- 440009, India
}

Corresponding Author: drrgreddy68@gmail.com

https://doi.org/10.46607/iamj3108112020

(Published online: November 2020)

Open Access

(C) International Ayurvedic Medical Journal, India 2020

Article Received: 06/11/2020 - Peer Reviewed: 12/11/2020 - Accepted for Publication: 18/11/2020

\section{Check for updates}

\begin{abstract}
In recent period of time Novel Corona virus has become the center point of attraction, due to it pandemic effect on the entire world. This pandemic disease has taken about a million of life and still its outbreak is continued. News reports have been addressing its origin in China by consumption of bats which were affected by Novel Corona virus (SARS-CoV2). Its spread in the entire world was a shock and the actual fact was unrevealed. Human beings live in an environment which is filled with various bacteria, fungus, virus and different types of animals since early life. But how this new bacteria or viruses get erupted, it is nothing but the effect of rapid modernization and urbanization. Since modernization and change in lifestyle of an individual is related to increase in demand of products which has forced the bar towards artificial world. Nature has been deteriorated for fulfilling the needs but still it is insufficient and in result natural energy /immunity is replaced by artificial. So human beings are more depended on artificial antibodies to safeguard themselves when they are attacked by different viruses or bacteria. China is a classic example of artificial food production and consumption state, so their people immunity is severely hampered, that result in the outbreak of virus. Similarly, this virus is affecting the entire world but still we have measures to fight this disease is by raising our immunity power. This can be done properly when we understand
\end{abstract}


the disease in a better manner. Ayurveda is the natural science, which helps us to understand the disease and the measure to increase immunity accordingly.

Keywords: Ayurveda, Novel Corona virus (SARS-CoV2), Lifestyle, Immunity.

\section{INTRODUCTION}

Ayurveda is the ancient science which has been developed thousands of years ago, has been enriched with all type of diseases and their treatment that affects human being by its basic principles of 'tri-dosha siddhant'. Human nature, behavior, habits, diet and lifestyle may change but 'tri-dosha' remains the same in more or less quantity as they were thousands of years ago. Since, Ayurveda has classified diseases mainly in two categories i.e. Nija and Agantuj; and also continued that this Agantuj vyadhi gets converted into Nija vyadhi in latter stage ${ }^{[1]}$. Therefore, every disease in universe has relation with dosha as they get converted in Nija stage ultimately after some time.

In recent times there is a disease called as Corona virus disease (COVID-19), which is considered to be caused by Corona virus or SARSCoV-2, which was thought to get originated from animal, but exact cause is still unknown. The existence of enumerated viruses in the universe cannot be denied but most of them are in inactive form. So how this inactive virus gets activated is a question, but as in Ayurveda there are various causes that has already mentioned which is related to activation of these viruses like Kala (time period or seasonal changes), Aahara (dietary habits) and Vihara (lifestyle changes) in relation to Asatmyaindryarthasanyoga-Parinam -Pradnyaparadh ${ }^{[2]}$. All these three factors are responsible in one or another way for the activation of virus or stimulating any disease. Although, any evolution occurs in surrounding is mainly affected by the Kala, which gets influence by Vihara of people. Similarly, health or immunity of an individual gets affected by Aahara which is consumed by that individual. It may lead to several diseases when it is not in proper nutritive manner.

Aim: To establish Ayurvedic perspective in Corona virus disease (Covid-19) in Relation with Sannipatik Jwara

\section{Objective:}

1. To study relation between cause of Corona virus disease (Covid-19) and Sannipatik Jwara

2. To highlight the cause of various viral and bacterial disease

3. To study the role of Ayurveda in treating various viral and bacterial disease

Methodology: Diagnosis of disease in Ayurveda is mainly based on Pramukha Lakshana (predominant sign and symptom) of that disease. According to sign and symptom of COVID-19 disease it resembles as 'Sannipatik Jwara'. As this 'Sannipatik Jwara' is also related to all of above three factors i.e. Kala-Parinam (time period or seasonal changes), Aahara (dietary habits) and Vihara (lifestyle changes) as Asatmyaindryarthasanyoga-Pradnyaparadh for its pathogenesis. 'Sannipatik Jwara' in Ayurveda have various different forms and is mainly consider as thirteen of them ${ }^{[3]}$; which varies in sign and symptom according to tara-tama of dosha. Similarly, it is seen in COVID-19 patients the disease resembles in various forms in some individual mild while in some severe even death has been occurred.

As the dietary habits and lifestyle in the recent era is getting worst and worst, more of artificial and hybrid food are available to fulfill need and earn more. All this affects the Agni (Jathargni) of an individual which results in the vitiation of Agni even more than the previous decades. When Agni gets vitiated severely than the food is not properly digested and results in formation of $\mathrm{Aam}^{[4]}$ more frequently. Aam formation is the root cause of any disease ${ }^{[5]}$. Frequent production of Aam results in vitiation of Annavaha and Rasavaha strotas that lead to pathogenesis of 'Sannipatik Jwara' and when these strotas is vitiated for prolong duration it results in Pranavaha strotas vitiation $^{[6]}$. The signs and symptoms like fever, anorexia, weakness, anxiety, fatigue, body ache, etc. are 
related to Rasavaha strotas vitiation; loose motion, dehydration which is due to vitiation of Annavaha Stotas; cough, cold, dyspnea, apnea, etc. are associated with Pranavaha strotas vitiation. Also every viral fever is Agantuja that requires kha-vaigunya for sthan-sanshrya in body, which is provided due to unhealthy lifestyle like sitting posture, travelling by twowheeler in pot holes, etc. that results into symptom like backache which is due to sthan-sanshrya of dosha in back region.

Any disease can be treated completely only when it has been properly understood. So, understanding a disease is very important, it doesn't mean naming the disease; but having knowledge of the disease by its lakshanas i.e. sign and symptoms, which help us to diagnose the disease. According to sign and symptom of COVID-19, it seems more likely to be a type of Jwara especially as Sanipatik Jwara. Also, Jwara is contagious disease ${ }^{[7]}$ similar to that of COVID-19 disease. Jwara is primarily the disease of Rasavaha strotas and Annavaha strotas and secondary it is Pranavaha strotas disease, so accordingly treatment has to be decided.

Etiological factors of Sanipatik Jwara ${ }^{[8]}$ are more similar to the lifestyle which we have adapted in recent times like vishamasana (irregular dietary habits), rutuvyapat (abnormality seasonal trends), asatmyagandha (unpleasant smell), vishyukt jalpan (toxicity in drinking water), garavishbakhshan (excess use of toxic pesticides or artificial preparation or adulteration of food), diwaswapna (day-sleep), jagran (awake at night doing night duties, chatting or watching movies), atimaithun (doing frequently sex activity), chinta (taking stress), irsha (getting jealous of others), krodha (anger), lobha (greediness) and due to any secondary disease that leads to dhatu kshya. All the three dosha gets vitiated due to these factors which is mostly present in city lifestyle. And importantly this Sanipatik Jwara is more effective in Vasanta, Varsha and Sharaddha ritu i.e. March-April, July-August and September-October respectively. Similarly, this pattern was observed in COVID-19 disease.

\section{DISCUSSION}

Prevalence ratios of COVID-19 as compare to urban cities is high than rural area and higher in more develop cities. This is due to the lifestyle and dietary habits adapted in different sector or class of society. In cities or Metro cities people over there have ruined all the lifestyle principle which has been mentioned in Ayurveda by performing night duties, irregular eating habits, fast and junk food consumption, suppression of natural urges, etc. that has affected Agni (Jatharagni) a lot and ultimate weak Agni is prone to any disease easily. But in rural area there are still directly or indirectly principles of Ayurveda are being followed like early to bed and early to rise, more of natural and healthy foodstuffs and more of physical activities in field, etc. which helps to keep their Agni in healthy condition and help them to fight against many diseases and early recovery if they encounter with a disease. Similarly, the death ratio is also high in cities than rural area.

COVID-19 disease is mainly related to agnimandya and it resemble more or less like Sanipatik Jwara. Since, there is no firm medication available with allopathic doctors, so it is better to use Ayurveda for prevention and treating the disease. It mainly affects the agni so strengthening the agni can helps to prevent the disease by rasayana or other immunity booster medicine.

\section{CONCLUSION}

COVID-19 disease is nothing but a man-made error which has created a nuisance to the world and like this many have been created again and again. It can be corrected when the human beings would start avoiding artificial or hybrid foodstuff and sacrifices their comfort lifestyle. Since, human body is not meant for it because it resembles Anupa desha which is full off disease people. So, people should follow healthy lifestyle and dietary habits as well as seasonal regimen as mentioned in Ayurveda to keep them-self healthy and fit.

In many countries and also in India COVID-19 patients have been reduced but it can relapse again. Since, the etiological factors are been continue and on 
the other hand people are waiting for vaccine i.e. artificial antibodies or immunity. Although, quitting the Hetu or etiological factors helps to raise natural immunity for COVID-19 and many such diseases.

\section{REFERENCES}

1. Dr. Bramhanand Tripathi, Charaka samhita, Sutra Sthana 11/45, Chaukhamba Surbharati Prakashan, Varanasi, 2010, page no. 244

2. Dr. Bramhanand Tripathi, Charaka samhita, Sutra Sthana 11/43, Chaukhamba Surbharati Prakashan, Varanasi, 2010, page no. 244

3. Dr. Bramhanand Tripathi, Charaka samhita, Chikitsasthana 3/90, Chaukhamba Surbharati Prakashan, Varanasi, 2013, page no. 140

4. Dr. Ganesh Krushna Garde, Sartha Vagbhat, Sutra Sthana 13/25, Chaukhamba Surbharati Prakashan, Varanasi, 2012, page no. 61

5. Prof. Yadunandan Upadhyaya, Madhava Nidanam, Madhukosa Commentary, 25/1-5, Chaukhamba Prakashan, Varanasi, 2012, page no. 509

6. Dr. Bramhanand Tripathi, Charaka samhita, Vimana Sthana 5/10, Chaukhamba Surbharati Prakashan, Varanasi, 2010, page no. 699

7. Kaviraja Ambikadutta Shastri, Susruta-samhita, vol. 1, Sutra sthana 35/21, Chaukhambha Sanskrit Sansthan, Varanasi, 2014, page no. 171.

8. Prof. Anant Damodar Aathavale, Ayurvediya Vyadhivinischaya, Jwara aadhya, Shri Radha Damodar Pratisthan, Pune, $2^{\text {nd }}$ edition, 1926, page no. 310

\section{Source of Support: Nil}

\section{Conflict of Interest: None Declared}

How to cite this URL: R. Govind Reddy \& Zaheer Z. Choudhari: Conceptual Study Of Corona Virus Disease (Covid-19) In Relation With Sannipatik Jwara: An Ayurvedic Perspective. International Ayurvedic Medical Journal \{online\} 2020 \{cited November, 2020\} Available from: http://www.iamj.in/posts/images/upload/5153 5156.pdf 